\title{
Hubungan Antara Pola Pemberian MP-ASI dengan Kejadian Stunting Anak Usia 6-23 Bulan di Kelurahan Karyamulya Kecamatan Kesambi Kota Cirebon
}

\author{
Maria Ulfah ${ }^{1}$ \\ ${ }^{1}$ Poltekes Bhakti Pertiwi Husada Cirebon Prodi Diploma IV Kebidanan \\ Jl. Kampung Melati 6A Kesambi Kota Cirebon \\ e-mail: maria.ahbib@gmail.com
}

\begin{abstract}
Abstrak Stunting merupakan kekurangan gizi kronis atau kegagalan pertumbuhan dimasa lalu dan digunakan sebagai indikator jangka panjang untuk gizi kurang pada anak. Penelitian ini bertujuan untuk mengetahui hubungan antara pola pemberian MP-ASI dengan kejadian stunting anak usia 6-23 bulan di Kelurahan Karyamulya Kecamatan Kesambi Kota Cirebon. Hasil penelitiannya adalah Pola pemberian MP-ASI pada anak usia 6-23 bulan di Kelurahan Karyamulya Kecamatan Kesambi Kota Cirebon adalah $22,4 \%$ baik, $57,9 \%$ cukup dan 19,7\% kurang. Kejadian stunting pada anak usia 6-23 bulan di Kelurahan Karyamulya Kecamatan Kesambi Kota Cirebon adalah 22,4\% mengalami stunting dan 77,6\% tidak stunting. Ada hubungan signifikan antara pola pemberian MP-ASI dengan kejadian stunting anak usia 623 bulan di Kelurahan Karyamulya Kecamatan Kesambi Kota Cirebon dengan p-value 0,000. Ibu anak usia 6-23 bulan hendaknya berusaha untuk dapat memberikan pola pemberian MP-ASI yang baik dan benar demi pertumbuhan dan perkembangan anak sehingga tidak menjadi stunting.
\end{abstract}

Kata Kunci : Pola Pemberian MP-ASI, Kejadian Stunting

Abstract, Stunting is a chronic malnutrition or past growth failure and is used as a long-term indicator of under-nutrition in children. This study aimed to determine the relationship between the pattern of MP-ASI administration and the incidence of stunting of children aged 6-23 months in Karyamulya Village Kesambi Town Cirebon. The results of this study were the pattern of MP-ASI administration in children aged 6-23 months in Karyamulya Village, Kesambi District, Cirebon City, which was 22.4\% good, 57.9\% sufficient and $19.7 \%$ less. The incidence of stunting in children aged 6-23 months in Karyamulya Village Kesambi District Cirebon City was $22.4 \%$ stunting and $77.6 \%$ not stunting. There is a significant relationship between the pattern of MP-ASI administration and the incidence of stunting of children aged 6-23 months in Karyamulya Village Kesambi Town Cirebon City in with a p-value of 0,000. Mothers of children aged 6 23 months should strive to be able to provide a pattern of giving good and correct complementary feeding for the growth and development of children so that they do not become stunting.

Keywords: Patterns of MP-ASI Giving, Stunting Events

\section{PENDAHULUAN}

Anak bawah dua tahun (Baduta) merupakan salah satu kelompok yang rawan gangguan kesehatan selain ibu hamil, ibu menyusui dan lanjut usia. Pada masa Baduta pertumbuhan sangat cepat diantaranya pertumbuhan fisik dan perkembangan psikomotorik, mental dan sosial. Baduta mempunyai resiko yang tinggi dan harus mendapatkan perhatian yang lebih. Semakin tinggi faktor risiko yang berlaku terhadap baduta tersebut maka akan semakin besar kemungkinan Baduta menderita pertumbuhan dan perkembangan yang tidak normal (Hendarto, 2008).

Proses tumbuh kembang baduta ditentukan sangat dipengaruhi oleh asupan gizi. Berbicara tentang tumbuh kembang baduta tidak akan terlepas dari berbicara tentang gizi. Sumber gizi terbaik bagi bayi usia 0-6 bulan adalah ASI eksklusif ditambah Makanan Pendamping ASI (MPASI) saat bayi usia 7-24 bulan. Untuk itu pemerintah telah mengembangkan vizi pembangunan gizi demi terwujudnya bayi dan balita yang dapat bertumbuh dan berkembang secara normal (Hildayani, 2010).

Stunting merupakan istilah para nutrinis untuk penyebutan anak yang tumbuh tidak sesuai dengan ukuran yang semestinya (anak pendek). Stunting (tubuh pendek) adalah keadaan tubuh yang sangat pendek hingga melampaui defisit 2 SD di bawah median panjang atau tinggi badan populasi yang menjadi referensi internasional. Stunting adalah keadaan dimana tinggi badan berdasarkan umur rendah, atau keadaan dimana tubuh anak lebih pendek dibandingkan dengan anak - anak lain seusianya. ditandai dengan terlambatnya 
pertumbuhan anak yang mengakibat-kan kegagalan dalam mencapai tinggi badan yang normal dan sehat sesuai usia anak. Stunting merupakan kekurangan gizi kronis atau kegagalan pertumbuhan dimasa lalu dan digunakan sebagai indikator jangka panjang untuk gizi kurang pada anak (Depkeu,2018).

Menurut WHO (2015) diperkirakan 25-35\% anak di dunia mengalami stunting. Di Indonsia dari hasi Pemantauan Status Gizi (PSG) 2016 ditemukan bahwa 37\% atau 9 juta anak yang penyebarannya 4,35 di Jawa, 2,29 Juta di Sumatera, 0,58 juta di Kalimantan, 0,77 juta di Sulawesi, 0,23 juta di NTB, 0,11 di Bali, 0,32 juta di NTT, 0,14 juta di Papua. Sedangkan untuk anak di bawah dua tahun atau baduta diketahui sebanyak 21,7\% mengalami stunting. Angka tersebut terdiri dari 7,1\% baduta dengan tinggi badan dengan status sangat pendek dan 14,6\% dengan status tinggi badan pendek (Depkeu, 2018)

Sedangkan di Jawa Barat, pada tahun 2017 tercatat sebanyak 43.788 baduta (Dinkes Jabar, 2018). Dan di Kota Cirebon tahun 2017 tercatat dari 22.749 baduta sebanyak 13,15\% mengalami stunting. Sementara di Kelurahan Karyamulya Kecamatan Kesambi Kota Cirebon berdasarkan data dari 7 posyandu yang ada diketahui dari 309 Baduta tercatat sekitar 57 baduta (21,5\%) mengalami stunting (Dinkes Kota Cirebon, 2018).

Menurut Soetjiningsih (2013), banyak faktor yang menyebabkan pertumbuhan dan perkembangan baduta menajdi stunting seperti asupan gizi selama kehamilan, riwayat BBLR, gagalnya pemberian ASI ekslusif, pola pemberian asupan MP-ASI yang tidak baik, dan pemberian imunisasi dasar yang tidak lengkap dan lain-lain.

Pertumbuhan dan perkembangan baduta yang kurang normal bisa disebabkan karena ketidaktahuan ibu mengenai tatacara pemberian ASI dan MP ASI yang baik kepada anaknya sehingga bayi tidak mendapat ASI eksklusif. Anak bayi belum mampu mengurus dirinya sendiri dengan baik, terutama dalam hal makanan (Soetjiningsih, 2013). Untuk dapat menyusun menu yang adekuat, seseorang perlu memiliki pengetahuan mengenai bahan makanan dan zat gizi, kebutuhan gizi seseorang serta pengetahuan hidangan dan pengolahannya. Dan yang terpenting masa bayi usia 0-6 bulan harus mendapat haknya untuk mendapatkan ASI eksklusif dan selajutnya harus mendapatkan haknya untuk mendapatkan ASI dan makanan pendamping ASI (MP ASI) yang baik dan bergizi (Soelistyaningsih, 2011).

Hasil observasi awal pada 10 ibu baduta yang mengalami stunting diketahui 6 ibu baduta memiliki pola pemberian MP ASI yang kurang baik dan hanya 4 ibu baduta yang pola pemberian MP ASI pada badutanya cukup baik.

Dari uraian di atas penulis tertarik untuk menganalisis hubungan antara pola pemberian MP-ASI dengan kejadian stunting anak usia 6-23 bulan di Kelurahan Karyamulya Kecamatan Kesambi Kota Cirebon.

\section{METODE PENELITIAN}

Jenis penelitian ini adalah penelitian deskriptif analitik dengan pendekatan cross sectional. Variabel dalam penelitian ini adalah variabel independent (pola Pemberian MP-ASI) dan variabel dependen (Kejadian Stunting). Dalam penelitian ini yang menjadi populasi adalah seluruh balita usia 6-23 bulan di Kelurahan Karyamulya Kota Cirebon. Jumlah sampel ditentukan dengan rumus Slovin yaitu 76 balita. Cara pengambilan sampelnya dengan accidental sampling. Instrumen penelitian ini terdiri dari instrument kuesioner dan lembar observasi SDIDTK. Karena data bersifat ordinal dan kategorik maka uji bivariat yang digunakan adalah korelasi Rank Spearman.

\section{HASIL PENELITIAN DAN PEMBAHASAN}

\section{Hasil Penelitian \\ 1. Biodata Responden}

Distribusi frekuensi biodata anak usia 6-23 bulan di Kelurahan Karyamulya Kecamatan Kesambi Kota Cirebon adalah 26,3\% berumur $<20$ tahun, 61,8\% berumur 20-35 tahun dan $11,8 \%$ berumur $>35$ tahun; 34,2\% berpendidikan dasar (SD/SMP Sederajat), 57,9\% menengah (SMA sederajat) dan 7,9\% tinggi (Perguruan Tinggi); 32,9\% berparitas primipara (1 anak), $60,5 \%$ multipara (2-4 anak) dan 6,6\% grandemultipara ( $>4$ anak). 


\section{Hasil Analisis Univariat}

Distribusi frekuensi pola pemberian MP-ASI pada anak usia 6-23 bulan di Kelurahan Karyamulya Kecamatan Kesambi Kota Cirebon adalah sebagai berikut :

\begin{tabular}{|l|l|l|}
\hline $\begin{array}{l}\text { Pola } \\
\text { Pemberian } \\
\text { MP-ASI }\end{array}$ & $\begin{array}{l}\text { Frekuensi } \\
\text { (F) }\end{array}$ & $\begin{array}{l}\text { Prosen- } \\
\text { tase (\%) }\end{array}$ \\
\hline Baik & 17 & 22,4 \\
\hline Cukup & 44 & 57,9 \\
\hline Kurang & 15 & 19,7 \\
\hline Jumlah & 76 & 100.0 \\
\hline
\end{tabular}

Berdasarkan tabel di atas, diketahui bahwa anak usia 6-23 bulan di Kelurahan Karyamulya yang menjadi responden penelitian hubungan antara pola pemberian MP-ASI dengan kejadian stunting anak usia 6-23 bulan di Kelurahan Karyamulya Kecamatan Kesambi Kota Cirebon adalah $22,4 \%$ pola pemberian MP-ASI-nya baik, 57,9\% cukup dan $19.7 \%$ kurang.

Distribusi frekuensi kejadian stunting anak usia 6-23 bulan di Kelurahan Karyamulya Kecamatan Kesambi Kota Cirebon adalah sebagai berikut :

\begin{tabular}{|l|l|l|}
\hline $\begin{array}{l}\text { Kejadian } \\
\text { Stunting }\end{array}$ & $\begin{array}{l}\text { Frekuensi } \\
\text { (F) }\end{array}$ & $\begin{array}{l}\text { Prosentase } \\
\text { (\%) }\end{array}$ \\
\hline Stunting & 17 & 22,4 \\
\hline $\begin{array}{l}\text { Tidak } \\
\text { Stunting }\end{array}$ & 59 & 77,6 \\
\hline Jumlah & 76 & 100.0 \\
\hline
\end{tabular}

Berdasarkan tabel di atas, diketahui bahwa anak usia 6-23 bulan di Kelurahan Karyamulya yang menjadi responden penelitian hubungan antara pola pemberian MP-ASI dengan kejadian stunting anak usia 6-23 bulan di Kelurahan Karyamulya Kecamatan Kesambi Kota Cirebon adalah 22,4\% mengalami stunting dan 77,6\% tidak stunting.

\section{Hasil Uji Bivariat}

Hasil tabulasi silang dan uji Rank Spearman hubungan antara pola pemberian MP-ASI dengan kejadian stunting anak usia 6-23 bulan di Kelurahan Karyamulya Kecamatan Kesambi Kota Cirebon adalah diketahui anak usia 6-23 bulan yang pola pemberian MP-asinya baik sama sekali tidak ada $(0,0 \%)$ yang mengalami kejadian stunting, sementara anak yang pola pemberian MP-ASI nya kategori cukup ada 11,4\% yang mengalami kejadian stunting dan anak yang pola pemberian ASI-nya kurang sebagian besar $(80,0)$ mengalami kejadian stunting. Karena p-value 0,000 < a 0,05 maka berarti Ho ditolak dan Ha diterima sehingga terbuktti bahwa bahwa ada hubungan signifikan antara pola pemberian MP-ASI dengan kejadian stunting anak usia 6-23 bulan di Kelurahan Karyamulya Kecamatan Kesambi Kota Cirebon.

Berdasarkan tabel di atas diketahui pula nilai koefesien korelasi Spearman atau Rho $(\rho)=-0,602$ yang dapat diinterpretasikan bahwa arah hubungannya negatif yaitu semakin baik pola pemberian MP-ASI maka semakin tidak stunting (semakin normal) dan sebaliknya. Berdasaran nilai Rho tersebut terlihat bahwa hubungan antara pola pemberian MP-ASI dengan kejadian stunting adalah kuat karena berada di rentang korelasi kuat $(0,51-0,75)$ selain itu juga dapat diketahui nilai koefesien determinasi $(\mathrm{KD})=\mathrm{Rho}^{2} \mathrm{x} 100 \%=-0,602 \mathrm{x}$ $0,602 \times 100 \%=36,2 \%$ atinya bahwa variabel pola pemberian MP-ASI memberikan pengaruh terhadap kejadian stunting pada balita sebesar $36,2 \%$ dan sisanya $63,8 \%$ dideterminasi oleh variabel lain selain variabel pola pemberian MP-ASI. 


\section{PEMBAHASAN}

Hasil penelitian menunjukkan bahwa pola pemberian MP-ASI pada anak usia 6-23 bulan di Kelurahan Karyamulya Kecamatan Kesambi Kota Cirebon adalah 22,4\% baik, 57,9\% cukup dan 19,7\% kurang.

Karakteristik responden penelitian yaitu ibu anak usia 6-23 bulan di Kelurahan Karyamulya Kecamatan Kesambi Kota Cirebon adalah 26,3\% berumur < 20 tahun, 61,8\% berumur 20-35 tahun dan 11,8\% berumur $>35$ tahun; 34,2\% berpendidikan dasar (SD/SMP Sederajat), 57,9\% menengah (SMA sederajat) dan 7,9\% tinggi (Perguruan Tinggi); 32,9\% berparitas primipara (1 anak), 60,5\% multipara (2-4 anak) dan 6,6\% grandemultipara (> 4anak).

Menurut teori Sulistyaningsih (2011) makanan pendamping ASI atau yang biasa disingkat dengan MP-ASI merupakan makanan dan minuman tambahan bergizi tinggi selain ASI yang diberikan kepada bayi untuk memenuhi kebutuhan gizinya. Jadi selain MP-ASI, ASI pun harus tetap diberikan kepada bayi, paling tidak sampai usia 24 bulan. MP-ASI berguna untuk menutupi kekurangan zat-zat gizi yang terkandung dalam ASI. Dengan demikian, jelas bahwa peranan MP-ASI bukan sebagai bahan makanan pengganti ASI, akan tetapi untuk mendampingi dan melengkapi ASI. MP-ASI merupakan suatu tahapan awal untuk memperkenalkan menu makanan bayi selain ASI. Pada tahapan ini bayi mulai dikenalkan makanan yang teksturnya sedikit padat. Hal ini dilakukan untuk mulai melatih ketrampilan motorik oral pada bayi. Ketrampilan motorik oral ini dilatih agar berkembang dari reflek menghisap menjadi menelan dengan memindahkan makanan dari lidah bagian depan ke belakang.

Hasil penelitian ini sesuai dengan hasil penelitian Meliana, dkk (2010) yang salah satu kesimpulannya menyebutkan hanya $25,5 \%$ responden balita yang pola pemberian MP-ASI-nya baik. Juga sejalan dengan hasil penelitian Wahyuningsih, dkk (2013) yang salah satu butir kesimpulannya menyebutkan bahwa hanya $23,7 \%$ balita yang pemberian MP-ASI-nya baik.

Hasil penelitian ini juga sejalan dengan hasil penelitian Al Rahmad (2014) yang salah satu kesimpulannya menyatakan bahwa pemberian MP-ASI pada balita $32,7 \%$ kurang. Hal ini diperkuat oleh penelitian Yulidasari (2012) yang juga menemukan bahwa 28,7\% pemberian MP-ASI pada balita tidak sehat.

Menurut analisis peneliti masih banyaknya fenomena anak usia 6-23 bulan yang tidak mendapatkan pola pemberian MP-ASI kurang baik (19,7\%) disebabkan oleh beberapa faktor, diantaranya umur ibu yang masih muda $<20$ tahun (ada 26,3\%), pendidikan ibu yang rendah (ada 34,2\%) sehingga pengetahuan ibu kurang memadai tentang MP-ASI, beredarnya mitos yang kurang baik tentang pemberian MP-ASI, serta kesibukan ibu dalam melakukan pekerjaannya dan paritas ibu yang primipara (ada 32,9\%) sehingga belum memiliki pengalaman dalam mengasuh anak. Umur yaitu usia individu yang terhitung mulai saat dilahirkan sampai saat berulang tahun. Semakin cukup umur maka tingkat kematangan dan kekuatan seseorang akan lebih matang dalam berpikir dan bekerja. Dalam kurun waktu reproduksi sehat dikenal bahwa usia aman adalah 20-35 tahun oleh sebab itu yang sesuai dengan masa reproduksi sangat baik karena dari segi fisik alat-alat reproduksi sudah siap dan matang demikian juga dari segi psikologis sudah dewasa dan sudah siap untuk menjadi seorang ibu yang harus mengurus dan mengasuh anak. Paritas yang primipara juga sering mengalami trauma pasca melahirkan seperti post partum blues atau depresi post partum yang dapat mengganggu kejiwaan ibu dalam mengasuh bayinya. Paritas primipara juga menunjukkan bahwa ibu belum pernah memiliki pengalaman mengasuh anak. Tingkat pendidikan ibu yang rendah mengakibatkan kurangnya pengetahuan ibu dalam menghadapi masalah, terutama dalam pola pemberian MP-ASI. Pengetahuan ini diperoleh baik secara formal maupun informal. Sedangkan ibu-ibu yang mempunyai tingkat pendidikan yang lebih tinggi (57,9\% menengah dan 7,9\% tinggi), umumnya terbuka menerima perubahan atau halhal baru guna pemeliharaan kesehatannya. Pendidikan juga akan membuat seseorang terdorong untuk ingin tahu, mencari pengalaman sehingga informasi yang diterima akan menjadi pengetahuan. Pendidikan diperkirakan ada kaitannya dengan pengetahuan ibu dalam memberikan Pola Pemberian MP-ASI, hal ini dihubungkan dengan tingkat pengetahuan ibu bahwa seseorang yang berpendidikan lebih tinggi akan mempunyai pengetahuan yang lebih luas dibandingkan dengan tingkat pendidiakan yang rendah.

Upaya untuk mengatasi masih banyaknya ibu yang belum bisa membeirkan MP-ASI sengan pola pemberian yang baik dan sehat sesuai standar diperlukan keterlibatan semua 
pihak terkait untuk mengatasinya. Salah satu cara mengatasinya adalah dengan meningkatkan lebih intensif lagi promosi kesehatan terutama tentang pola pemberian MPASI pada para ibu balita bisa melalui kelas khusus, saat posyandu, arisan, pengajian atau dengan memberikan brosur petunjuk pola pemberian MP-ASI yang baik dan benar kepada seluruh ibu balita.

Hasil penelitian menunjukkan bahwa kejadian stunting pada anak usia 6-23 bulan di Kelurahan Karyamulya Kecamatan Kesambi Kota Cirebon adalah 22,4\% mengalami stunting dan 77,6\% tidak mengalam stunting.

Menurut teori Depkes RI (2013) stunting merupakan istilah para nutrinis untuk penyebutan anak yang tumbuh tidak sesuai dengan ukuran yang semestinya (anak pendek). Stunting (tubuh pendek) adalah keadaan tubuh yang sangat pendek hingga melampaui defisit 2 SD di bawah median panjang atau tinggi badan populasi yang menjadi referensi internasional. Stunting adalah keadaan dimana tinggi badan berdasarkan umur rendah, atau keadaan dimana tubuh anak lebih pendek dibandingkan dengan anak - anak lain seusianya. ditandai dengan terlambatnya pertumbuhan anak yang mengakibatkan kegagalan dalam mencapai tinggi badan yang normal dan sehat sesuai usia anak. Stunting merupakan kekurangan gizi kronis atau kegagalan pertumbuhan dimasa lalu dan digunakan sebagai indikator jangka panjang untuk gizi kurang pada anak.

Hasil penelitian ini sesuai dengan hasil penelitian Meliana, dkk (2010) yang salah satu kesimpulannya menyebutkan terdapat $20,7 \%$ responden yang stunting.. Juga sejalan dengan hasil penelitian Wahyuningsih, dkk (2013) yang salah satu butir kesimpulannya menyebutkan bahwa hanya $26,2 \%$ balita mengalami stunting.

Hasil penelitian ini juga sejalan dengan hasil penelitian Al Rahmad (2014) yang salah satu kesimpulannya menyatakan bahwa $22,3 \%$ balita mengalami stunting. Hal ini diperkuat oleh penelitian Yulidasari (2012) yang juga menemukan bahwa 24,1\% balita mengalami stunting.

Menurut analisis peneliti, masih banyaknya anak usia 6-23 bulan di Kelurahan Karyamula yang mengalami kejadian stunting berkaitan erat dengan usia ibu, paritas ibu dan pekerjaan ibu selain itu juga disebabkan pola pemberian MP-ASI.

Mengingat stunting pada balita akan mempengaruhi kualitas generasi masa depan bangsa maka harus segera diambil langkah-langkah guna mengatasi atau minimal mengurangi kejadian stunting pada balita salah satu caranya adalah dengan menyadarkan para ibu balita akan arti penting asupan gizi bagi pertumbuhan balita. Pentingnya juga lebih diintensifkan program pemberian makanan tambahan kepada balita setiap ada kegiatan posyandu.

Hasil penelitian dan uji Spearman hubungan antara pola pemberian MP-ASI dengan kejadian stunting anak usia 6-23 bulan di Kelurahan Karyamulya Kecamatan Kesambi Kota Cirebon didapatkan nilai koefesien korelasi Spearman atau Rho $(\rho)=-0,602$ dengan sig atau p-value $0,000<a \quad 0,05$ sehingga terbukti bahwa ada hubungan signifikan antara pola pemberian MP-ASI dengan kejadian stunting anak usia 6-23 bulan di Kelurahan Karyamulya Kecamatan Kesambi Kota Cirebon.

Adanya hubungan tersebut secara deksriptif dapat dilihat dari data bahwa anak usia 623 bulan yang pola pemberian MP-ASI-nya baik sama sekali tidak ada $(0,0 \%)$ yang mengalami kejadian stunting, sementara anak yang pola pemberian MP-ASI nya kategori cukup ada $11,4 \%$ yang mengalami kejadian stunting dan anak yang pola pemberian ASI-nya kurang sebagian besar $(80,0)$ mengalami kejadian stunting.

Menurut teori Ngastiah (2013) pola pemberian MP-ASI pada anak mulai usia 6 bulan akan membuat anak mendapatkan asupan nutrisi yang terbaik sekaligus membuat anak memiliki imunitas yang tinggi. Tentu saja hal ini akan terjadi jika pola pemberian MP-ASIdengan cara yang benar sehingga anak akan mendapatkan asupan gizi yang cukup.

Menurut teori Prasetyo (2009) pola pemberian MP-ASI pada anak mulai usia 6 bulan dengan pola yang baik dan benar akan menyebabkan ratuan bahan nutrisi antara lain protein, lemak, karbohidrat, vitamin, mineral, faktor pertumbuhan, hohmon, enzim, zat imunitas, sel darah putih semuanya akan masuk dan terserap ke dalam tubuh anak usia 6-23 bulan secara proporsioanl dengan kesimbangan biokimia yang sangat tepat bagai suatu simfoni nutrisi bagi kesehatan anak usia 6-23 bulan sehingga anak usia 6-23 bulan akan tumbuh dan berkembang dengan sehat dan normal karena zat-zat yang diserap anak usia 623 bulan dari MP-ASI tersebut akan membangun sistem kekebalan tubuh anak usia 6-23 bulan sehingga kesehatan anak usia 6-23 bulan akan baik karena anak usia 6-23 bulan 
memiliki imunitas terhadap serangan penyakit. Kekebalan atau imunitas anak ditejadi karena pola pemberian MP-ASI nya baik maka akan tumbuh kembang secara normal dan tidak akan mengalami kejadian stunting.

Hasil penelitian ini sesuai dengan teori dari Hayati (2009) bahwa, kejadian stunting pada anak merupakan suatu proses kumulatif yang terjadi sejak kehamilan, masa kanakkanak dan sepanjang siklus kehidupan. Pada masa ini merupakan proses terjadinya stunting pada anak dan peluang peningkatan stunting terjadi dalam 2 tahun pertama kehidupan. Faktor gizi ibu sebelum dan selama kehamilan merupakan penyebab tidak langsung yang memberikan kontribusi terhadap pertumbuhan dan perkembangan janin. Ibu hamil dengan gizi kurang akan menyebabkan janin mengalami intrauterine growth retardation (IUGR), sehingga bayi akan lahir dengan kurang gizi, dan mengalami gangguan pertumbuhan dan perkembangan. Anak-anak yang mengalami hambatan dalam pertumbuhan disebabkan kurangnya asupan makanan yang memadai dan penyakit infeksi yang berulang, dan meningkatnya kebutuhan metabolic serta mengurangi nafsu makan, sehingga meningkatnya kekurangan gizi pada anak. Keadaan ini semakin mempersulit untuk mengatasi gangguan pertumbuhan yang akhirnya berpeluang terjadinya stunting. Gizi buruk kronis (stunting) tidak hanya disebabkan oleh satu faktor saja seperti yang telah dijelaskan diatas, tetapi disebabkan oleh banyak faktor, dimana faktor-faktor tersebut saling berhubungan satu sama lainnnya. Terdapat tiga faktor utama penyebab stunting yaitu asupan makanan tidak seimbang (berkaitan dengan kandungan zat gizi dalam makanan yaitu karbohidrat, protein,lemak, mineral, vitamin, dan air); riwayat berat badan lahir rendah (BBLR) dan riayat penyakit.

Hasil penelitian ini sesuai dengan teori Arisman (2014) bahwa pertumbuhan dan perkembangan baduta yang kurang normal bisa disebabkan karena ketidaktahuan ibu mengenai tatacara pemberian ASI dan MP ASI yang baik kepada anaknya sehingga bayi tidak mendapat ASI eksklusif. Anak bayi belum mampu mengurus dirinya sendiri dengan baik, terutama dalam hal makanan. Pada umumnya anak-anak yang masih kecil (baduta) mendapat makanannya secara dijatah oleh ibunya dan tidak memilih serta mengambil sendiri mana yang disukainya. Untuk dapat menyusun menu yang adekuat, seseorang perlu memiliki pengetahuan mengenai bahan makanan dan zat gizi, kebutuhan gizi seseorang serta pengetahuan hidangan dan pengolahannya. Dan yang terpenting masa bayi usia 0-6 bulan harus mendapat haknya untuk mendapatkan ASI eksklusif dan selajutnya harus mendapatkan haknya untuk mendapatkan ASI dan makanan pendamping ASI (MP ASI) yang baik dan bergizi

Hasil penelitian ini sesuai dengan penelitian Meliana, dkk (2010) menyimpulkan bahwa ada hubungan pemberian MP-ASI dengan kejadian stunting anak usia 6-23 bulan dengan pvalue 0,007. Juga sejalan dengan hasil penelitian Wahyuningsih, dkk (2013) menyebutkan bahwa kegagalan pola pemberian MP-ASI merupakan salah satu faktor yang mempengaruhi kejadian stunting pada baduta dengan p-value 0,002.

Hasil penelitian ini juga sejalan dengan hasil penelitian Al Rahmad (2014) yang menyatakan bahwa ada hubungan antara kualitas pemberian MP-ASI dengan kejadian stunting pada balita dengan p-value 0,009. Hal ini diperkuat oleh penelitian Yulidasari (2012) yang juga menemukan bahwa ada pengaruh signifikan pola pemberian MP-ASI dengan kejadian stunting pada balita dengan $\mathrm{p}$-value 0,003 .

Jadi adanya pola pemberian MP-ASI yang baik maka anak usia 6-23 bulan sudah mendapat asupan nutrisi dan imunitas terbaik sejak dini dan ini menjadi modal dasar untuk proses tumbuh kembang anak usia 6-23 bulan. Diduga kuat anak usia 6-23 bulan yang memiliki pola pemberian MP-ASI akan memiliki tumbuh kembang lebih baik dibandingkan anak usia 6-23 bulan yang tidak medapatkan pola pemberian MP-ASI baik.

Oleh karena terbukti bahwa MP-ASI memiliki hubungan signifikan dengan kejadian tumbuh kembang pada anak usia 6-23 bulan maka diharapkan semua ibu mulai dari kehamilannya sampai kelahirannya terus melakukan persiapan untuk bisa memberikan pola pemberian MP-ASI dengan baik.

\section{KESIMPULAN DAN SARAN}




\section{Kesimpulan}

1. Pola pemberian MP-ASI pada anak usia 6-23 bulan di Kelurahan Karyamulya Kecamatan Kesambi Kota Cirebon adalah 22,4\% baik, 57,9\% cukup dan 19,7\% kurang.

2. Kejadian stunting pada anak usia 6-23 bulan di Kelurahan Karyamulya Kecamatan Kesambi Kota Cirebon adalah 22,4\% mengalami stunting dan 77,6\% tidak stunting.

3. Ada hubungan signifikan antara pola pemberian MP-ASI dengan kejadian stunting anak usia 6-23 bulan di Kelurahan Karyamulya Kecamatan Kesambi Kota Cirebon dengan pvalue 0,000 .

\section{Saran}

1. Bagi Ibu

Ibu anak usia 6-23 bulan hendaknya berusaha untuk dapat memberikan pola pemberian MP-ASI yang baik dan benar demi pertumbuhan dan perkembangan anak sehingga tidak menjadi stunting.

2. Bagi Petugas Kesehatan/Bidan

Petugas kesehatan khususnya bidan diharapkan dapat memberikan penyuluhan tentang arti penting dan cara-cara memberikan MP-ASI yang baik dan benar sekaligus memberian contoh pola pemberian MP-ASI yang baik.

3. Bagi Pihak Kelurahan \& Puskesmas

Pihak kelurahan dan puskesmas hendaknya terus meningkatkan status gizi baduta di wilayahnya melalui promosi kesehatan baik formal seperti kelas ibu hamil maupun informal seperti komunikasi dan konseling bidan desa mengenai pola pemberian MPASI pada ibu-ibu dalam kegiatan posyandu agar para ibu termotivasi untuk selalu memberikan pola pemberian MP-ASI yang ekslusif pada anak usia 6-23 bulannya sehingga anak usia 623 bulan bisa tumbuh dan berkembang secara baik dan normal dan tidang mengalami stunting.

4. Bagi peneliti lain

Diharapkan dapat melakukan penelitian lanjutan tentang masalah stunting dengan vriabel yang lebih variatif lagi.

\section{DAFTAR PUSTAKA}

Arisman, S. 2014. Bijak Memberikan MP-ASI. Yogyakarta: Pustaka Pelajar

Depkes RI. 2013. Mengukur Status Gizi Balita Jakarta. Direktorat Bina Gizi Masyarakat. Depkes RI

Dinkes Kota Cirebon, 2018, Laporan Kesehatan Kota Cirebon Tahun 2017

Hendarto, A \& Pringgadini, K,. 2008. ASI dan Tumbang Bayi Jakarta : Balai Penerbit FKUI.

Hayati, 2009. Strategi Menyiapkan Menu Makanan Pendamping ASI (MP-ASI) untuk bayi 6 24 bulan, Jakarta : Gramedia

Notoatmodjo, 2012. Metodologi Penelitian Kesehatan. Jakarta: PT Rineka Cipta

Prasetyono, Dwi Sunar. 2009. Buku Pintar ASI Eksklusif. Diva Press; Jogjakarta

Roesli, Utami. 2008. Inisiasi Menyusui Dini. Jakarta : Pustaka Bunda.

Rini, Hindayani, 2010. Perkembangan Balita, Jakarta : Granada

Sulistyaningsih, Hariyani. 2011. Gizi Untuk Kesehatan Ibu dan Anak. Yogyakarta: Graha Ilmu.

Soejtiningsih. 2013. Tumbuh Kembang Anak. Jakarta: EGC 